\title{
A Novel Nested Polymerase Chain Reaction (n-PCR) Assay for Identifying Sorghum nitidum
}

\author{
Shasha WEI ${ }^{1}$, Zhirui DENG ${ }^{1}$, Liping YIN² ${ }^{2}$ Jianping YI², Renqi WU', Qin CHEN* \\ ${ }^{1}$ Shanghai University, School of Life Science, Shanghai Key Laboratory of Bio-Energy Crops, \\ 200444,Shanghai,China chenqincc@yahoo.com.cn ( ${ }^{*}$ corresponding author) \\ ${ }^{2}$ Shanghai Entry-Exit Quarantine and Inspection Bureau, 200135, Shanghai, China
}

\begin{abstract}
This work developed a novel nested polymerase chain reaction (n-PCR) assay to identify Sorghum nitidum (S. nitidum). It has been designed a set of specific n-PCR inner primers Snit5/Snit2 and outer primers Nout1/Nout2 based on a conserved nucleotide sequence of adh1-like gene of $S$. nitidum. Fourteen samples of sorghum were used to investigate the specificity of the primers and the n-PCR assay. The result showed that 9 samples of $S$. nitidum displayed a positive strong, specific amplified band at $\sim 873$ bp in gel spectra, while other relatives, including Sorghum halepense, Sorghum almum, Sorghum bicolor, Sorghum propinum and Sorghum sudanse exhibited negative amplifications. This assay was able to specifically identify $S$. nitidum fast and effectively, which could be applied widely in field inspection, agriculture production and plant protection.
\end{abstract}

Keywords: Sorghum nitidum, nested polymerase chain reaction (n-PCR), molecular detection

\section{Introduction}

Sorghum nitidum is a related species of the hard weed Sorghum halepense (Guo et al., 1996), which originated from west of India and then spread widely into southeast Asia, Indonesia and Australia. Sorghum Moench could be classified into five groups, namely Stiposorghum, Parasorghum, Eusorghum, Heterosorghum and Chaetosorghum (Celarier, 1959; DeWet, 1978), while S. nitidum was recognized to be one of the most widely spreading species in the group of Parasorghum (Snowden, 1955). Like $S$. halepense and $S$. almum, $S$. nitidum is a perennial weed and the chromosome is as big as $S$. halepense and $S$. biocolor. Sun et al. (1994) believed that the $S$. nitidum should be cataloged into the Eusorghum group, while DeWet et al. (1978) thought $S$. nitidum should be classified into the Parasorghum group. The correct relationship of $S$. nitidum should be further studied. It is very difficult to distinguish the seed of different sorghum species morphologically from each other (Guo et al., 1996). Because seeds of $S$. nitidum among farm products may be deformed and abraded during storage, loading and unloading, in addition, the morphology of the sorghum seed usually impacted by the environment, climate, condition of maturation. The method of cellular diagnostics would also be very tedious and time - consuming, which would not be very suitable for field detection (Harlan and De Wet, 1974).

ADH (Ethanol Dehydrogenase, EC 1.1.1.1), coded by the gene $a d h$, which was widely distributed over various organs and tissues throughout the plant, catalyzes the conversion between the ethanol and acetaldehyde. Sivaraman et al. (1984) was the first to study the DNA polymorphism of the adh gene of Arabidopsis. The polymorphism of the adh gene could help discover the genetic relationship between different species and provide biological dates for identifying some specific species.

Nested PCR (n-PCR) originated from the typical PCR technique, which has been widely used in basic biological researches and clinical diagnostics (Khan et al., 2004; Mayer and Palmer, 1996; Tanzer, 2000). The basic principle of n-PCR based on two pairs of specific primers designed to amplify one gene fragment by two round thermo-cycling. N-PCR technique could decrease the pseudo-positive amplification and improve the sensitivity of the assay. In this work, we designed a set of specific nPCR primers based on a conserved nucleotide gene fragment of adb1-like gene of $S$. nitidum and developed a fast assay to identify the $S$. nitidum with high specificity and effectivity.

\section{Materials and methods}

\section{Materials}

Fourteen sorghum samples were obtained from Shanghai Entry-Exit Inspection and Quarantine Bereau (China) among which 9 samples were $S$. nitidum, others were $S$. halepense, S. almum, S. bicolor, S. propinum and S. sudanse, respectively (Tab. 1). 
144

Tab. 1 Samples of sorghum used in this work

\begin{tabular}{cccc}
\hline Number & The latin name & Origin & Original number \\
\hline Snit1 & S. nitidum & Austrlia & AusTRCF302539 \\
Snit2 & S. nitidum & Austrlia & AusTRCF302540 \\
Snit3 & S. nitidum & Austrlia & AusTRCF302542 \\
Snit4 & S. nitidum & Austrlia & AusTRCF302543 \\
Snit5 & S. nitidum & Austrlia & AusTRCF302558 \\
Snit6 & S. nitidum & Austrlia & AusTRCF302559 \\
Snit7 & S. nitidum & Austrlia & AusTRCF316841 \\
Snit8 & S.nitidum & Austrlia & AusTRCF316922 \\
Snit9 & S.nitidum & Austrlia & AusTRCF316930 \\
Shall & S. halepense & America & - \\
Salm1 & S. almum & Argentina & - \\
Sbic1 & S. bicolor & Unknown & - \\
Spro1 & S. propinum & China & - \\
Ssud1 & S. sudanse & China & - \\
\hline
\end{tabular}

Tab. 2. The Genbank number of the sorghum for analyzing the conserved nucleotide sequence of the $S$. nitidum

\begin{tabular}{|c|c|c|c|}
\hline $\begin{array}{l}\text { Genbank } \\
\text { Number }\end{array}$ & Latin Name & $\begin{array}{c}\text { Genbank } \\
\text { Number }\end{array}$ & Latin Name \\
\hline DQ096188.1 & S. nitidum & DQ096172.1 & S. macrospermum \\
\hline DQ096165.1 & S. bicolor & DQ096174.1 & S. exstans \\
\hline AF050456.1 & S. bicolor & DQ096175.1 & S. grande \\
\hline AF124045.1 & S. bicolor & DQ096176.1 & S.plumosum \\
\hline DQ096167.1 & S. $x$ almum & DQ096177.1 & S. bulbosum \\
\hline FJ650402.1 & S. xalmum & DQ096178.1 & S. stipoideum \\
\hline FJ650403.1 & S. $x$ almum & DQ096179.1 & S. amplum \\
\hline FJ650405.1 & S. xalmum & DQ096180.1 & S. intrans \\
\hline FJ650407.1 & S. $x$ almum & DQ096181.1 & S. ecarinatum \\
\hline DQ096168.1 & S. halepense & DQ096182.1 & S. angustum \\
\hline FJ650404.1 & S. halepense & DQ096183.1 & S. matarankense \\
\hline FJ650406.1 & S. halepense & DQ096184.1 & S. interjectum \\
\hline DQ096169.1 & S. $x$ drummondii & DQ096185.1 & S. timorense \\
\hline FJ650408.1 & S. $x$ drummondii & DQ096186.1 & S. brachypodum \\
\hline DQ096166.1 & S. arundinaceum & DQ096187.1 & S. leiocladum \\
\hline DQ096170.1 & S. propinquum & DQ096189.1 & S. purpureosericeum \\
\hline FJ650401.1 & S.sp. 'Silk' & DQ096190.1 & S. versicolor \\
\hline DQ096171.1 & S. laxiflorum & & \\
\hline
\end{tabular}

Tab. 3. Outer primers of n-PCR for identification of the $S$. nitidum

\begin{tabular}{cc}
\hline Primer & Nucletide sequence \\
\hline Nout1 & 5' CCGTGATTTCTCCTCTG 3' \\
Nout4 & 5' CGGGAGCTACATCAGTC 3' \\
\hline
\end{tabular}

Tab. 4. Typical PCR primers for identification of the $S$. nitidum

\begin{tabular}{cc}
\hline Primer & Nucletide sequence \\
\hline Snit5 & 5' TTGCTATAGAACTTTCTAGC 3' \\
Snit2 & 5' ACAGCCCTAGTTGTACTG 3' \\
\hline
\end{tabular}

Extraction of genomic DNA form a seed of sorghum

Total Genomic DNA was extracted from a single seed of sorghum using an improved method developed in our laboratory (Chen et al., 2009). After verified by the aga- rose gel electrophoresis and NanoDrop ND-1000 spectrophotometer (NanoDrop Technologies, Montchanin, DE, USA), the genomic DNA was stored at $4^{\circ} \mathrm{C}$.

\section{N-PCR primers design for identifying S. nitidum}

The discrimination of the nucleotide sequence of the adh I-like gene between the $S$. nitidum and other sorghum species were analyzed by the sorfware Cluster X. The typical PCR primers were designed based on a conserved gene fragment of $S$. nitidum (Tab. 2). The outer primers of nPCR for the $S$. nitidum were shown as Tab. 3, while the inner $\mathrm{n}-\mathrm{PCR}$ primers were as the same as the primer of typical PCR (Tab. 4).

\section{Typical PCR method}

The typical PCR for identifying $S$. nitidum was performed in a volume of $20 \mu \mathrm{L}$ system including $\mathrm{ddH}_{2} \mathrm{O}$ $12.8 \mu \mathrm{l}$, PCR buffer $2 \mu \mathrm{l}, \mathrm{Mg}^{2+} 1.2 \mu \mathrm{l}, \mathrm{dNTP}(2.5 \mathrm{mmol} / \mathrm{L})$ $0.5 \mu \mathrm{l}, \mathrm{rTaq}$ DNA polymerase $(5 \mathrm{U} / \mu \mathrm{l}) 0.2 \mu \mathrm{l}$, Primer Snit 5 $(20 \mu \mathrm{mol} / \mathrm{L}) 1 \mu \mathrm{l}$, Primer Snit2 $(20 \mu \mathrm{mol} / \mathrm{L}) 1 \mu \mathrm{l}$ and template DNA $1 \mu \mathrm{l}$. The PCR was carried out in a thermocycler, commenced with $3 \mathrm{~min}$ at $94^{\circ} \mathrm{C}$, followed by the 35 cycles of 30 s at $94^{\circ} \mathrm{C}, 30$ s at $50^{\circ} \mathrm{C}$ and 80 s at $72^{\circ} \mathrm{C}$, finally ended with $6 \mathrm{~min}$ at $72^{\circ} \mathrm{C}$. The amplified product was analyzed by the agarose gel electrophoresis and the result was visualized and recorded by the gel documentation system.

\section{Nested PCR method}

The n-PCR was performed in a volume system of 20 $\mu \mathrm{l}$, which include dd $\mathrm{H}_{2} \mathrm{O} 12.8 \mu \mathrm{l}$, PCR buffer $2 \mu \mathrm{l}, \mathrm{Mg}^{2+}$ $1.2 \mu \mathrm{l}, \mathrm{dNTP}(2.5 \mathrm{mmol} / \mathrm{L}) 0.5 \mu \mathrm{l}$, rTaq DNA polymerase (5 U/ $\mu \mathrm{l}) 0.2 \mu \mathrm{l}$, Primer Nout $1(20 \mu \mathrm{mol} / \mathrm{L}) 1 \mu \mathrm{l}$, Primer Nout $4(20 \mu \mathrm{mol} / \mathrm{L}) 1 \mu \mathrm{l}$ and template DNA $1 \mu \mathrm{l}$. The amplification was carried out with the commence of $3 \mathrm{~min}$ pre-denaturing at $94^{\circ} \mathrm{C}$, followed by the 20 cycles of $30 \mathrm{~s}$ denaturing at $94^{\circ} \mathrm{C}, 30 \mathrm{~s}$ annealing at $50^{\circ} \mathrm{C}$ and elongation $80 \mathrm{~s}$ at $72^{\circ} \mathrm{C}$. The second amplification system was as the same as the first round PCR, other than the primers and the template DNA, while the number of thermo-cycles was adjusted to 20 cyclers in the second round. The amplified product was separated by the agarose gel electrophoresis and analyzed by gel documentation system.

\section{Results and discussion}

\section{Establishment of typical-PCR assay for identifying} sorghum nitidum

Primers of typical PCR Snit5/Snit2 were used to amplify the genomic DNA extracted from a single seed of S. nitidum. The result was shown in Fig. 1, from which, a strong, specific band at $\sim 873$ bp appeared, according well with our predicting.

\section{The application of the typical-PCR}

The specificity of the typical PCR assay was verified using 2 samples of $S$. nitidum and 1 sample of $S$. halepense. 


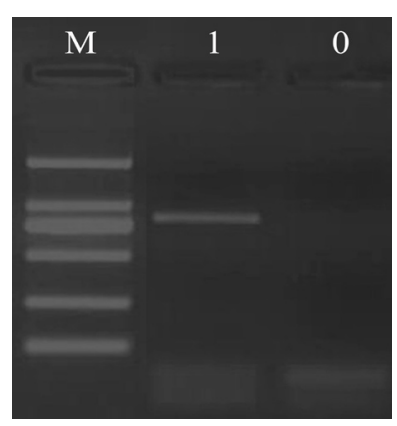

Fig. 1. Typical PCR for identification of the S. nitidum; M: Marker (DL 2000); 1: Snit 1; 0: Blank

The result was as shown in Fig. 2, from which, we observed that a specific amplified band occurred to the sample of $S$. nitidum while there was no positive signal to the $S$. halepense, indicating the high specificity of the assay.

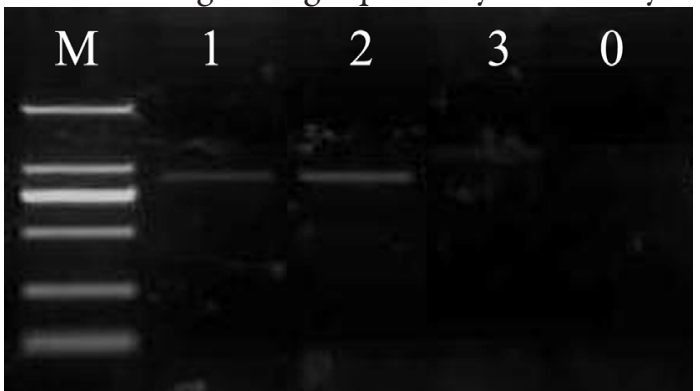

Fig. 2. The spcificity of the typical PCR; M: Marker(DL 2000); 1: Snit 1; 2: Snit2; 3: Shal1; 0: Blank

\section{Establishment of nested PCR assay for identifying $S$. nitidum}

We made use of primers Nout1/Nout 4 and Snit5/ Snit 2 to amplify the genomic DNA extracted from a single seed of $S$. nitidum. The result was as shown in Fig. 3, from which, we could observe a strong specific band at $\sim 873 \mathrm{bp}$, which was well accorded with our predicting.

\section{The application of $n-P C R$}

We used the n-PCR assay established above to detect 14 sorghum samples. The result was as following (Fig. 4). Samples 1-9 displayed strong specific amplified band at $\sim 873$ bp while other samples exhibited negative amplification on the electrophoretic gel. As a matter of fact, these 9 samples were confirmed to be $S$. nitidum while others were $S$. halepense, S. almum, S. bicolor, $S$. propinum and $S$. sudanse. The reproducibility of the n-PCR assay was con-

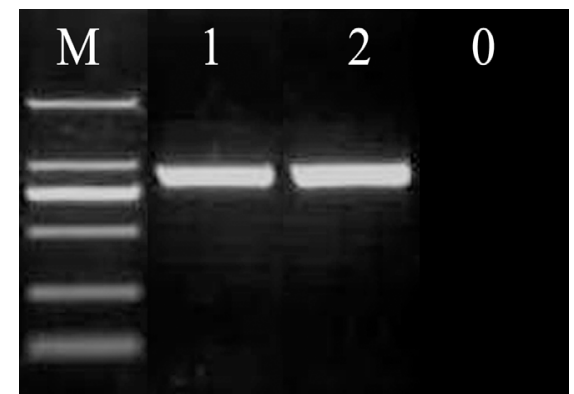

145

Fig. 3. Nested PCR for identification of the $S$. nitidum; M: Marker(DL 2000); 1: Snit 1; 2: Snit2; 3: Blank

firmed to be higher than typical PCR after many tests and meet the requirement of clinical applications.

The specificity of the PCR primers is very critical to the PCR assay. In this study, we compared the nucleotide sequence of the adh1-like gene between the $S$. nitidum and other 28 sorghum species using the software Cluster X. The analysis showed the great discrimination of the adh1like gene of the $S$. nitidum with other sorghum species. Although the high-similarity of the nucleotide sequence of adh 1 gene with the $S$. leiocladum, there is a great diversity within the gene fragment of 1035-1068 bp. Therefore, we designed a backward primer in the gene region of 1035 $1068 \mathrm{bp}$, while the forward primer was designed in the low-similarity gene fragment, which would like to guarantee the high specificity of the primers for identifying the $S$. nitidum. After all, the high-specificity of the primers was the technical foundation of the nested-PCR assay.

The reason of the low-efficiency of the typical PCR when compared with the nested PCR is as follows: 1) the space/advanced structure of the adh1-like gene may be very complex; 2) the number of the loci of adh1-like gene is small throughout the genomic gene of the sorghum, which reduce the target number and the amplification efficiency. In order to proof the first suggestion, we designed series of primers targeting at the nucleotide fragment throughout 2000 bp nucleotide acids near the adh1-like gene. However, all of the primers showed low-efficient amplification, which tells us that the first reason seems not like exit. In order to verify the second reason, we blast the adb1-like loci in the database of S. bicolor and observed that there is only one locus in the genome of the sorghum. Therefore, typical PCR would possibly displayed low-efficiency; especially the DNA concentration is low in the amplification system. Wen WG et al. (2008) applied the

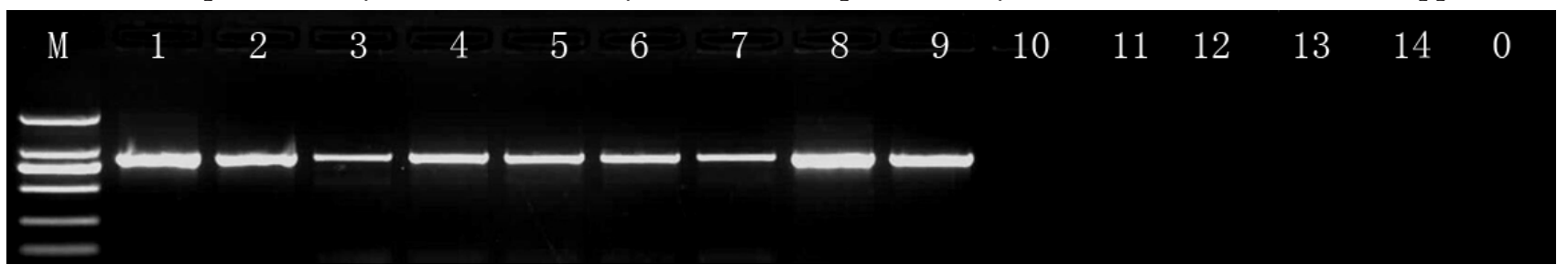

Fig. 4. The specificity of the n-PCR for identifying the S. nitidum; M, DL2000 (TAKARA); 1 9, Snit1 Snit9; 10, Shal1; 11, Salm 1; 12, Sbic1; 13, Spro1; 14, Ssud1, 0, Blank 
146

semi-nested PCR assay to detect the genetically modified rice in the food and observed the high sensitivity of the assay when compared with the typical PCR. Nested PCR was much more specific and sensitive than typical PCR and the stability of the n-PCR could be very good in some cases. We herein established a novel n-PCR assay for fast and reproducible detection of the $S$. nitidum.

\section{Conclusions}

A set of specific n-PCR inner primers Snit5/Snit2 and outer primers Nout1/Nout2 based on a conserved nucleotide sequence of adh1-like gene of $S$. nitidum was designed. A novel nested polymerase chain reaction (nPCR) assay to identify Sorghum nitidum (S. nitidum) was developed. This assay was able to specifically identify $S$. nitidum fast and effectively, which could be applied widely in field inspection, agriculture production and plant protection.

\section{Acknowledgements}

The research was supported by project of PRC State Administration for Quality Supervision Inspection and Quarantine (AQSIQ) No. 200810787, Shanghai University No. SHUCX102290.

\section{References}

Celarier RP (1959). Cytotaxonomy of the Andropogoneae, III. subtribe Sorgheae, genus Sorghum. Cytologia 23:395-418.

Chen Q, Wei SS, Deng ZR, Yin LP, He B, Kong XL (2009). Optimization of DNA extraction from seeds of Sorghum sudanense (Piper) Stapf. Not Bot Horti Agrobo 37(1):25660.

DeWet JMJ (1978). Systematic sand evolution of sorghumsect, Sorghum (Graminae). Am J Bot 65:477-484.
Guo JH, Skinner DZ, Liang GH (1996). Phylogenetic relationships of sorghum taxa inferred from mitochondrial DNA restriction fragment analysis. Genome 39(5):10271034.

Harlan JR, De Wet JMJ (1974). Symposium NO.9: Origin of cultivated plants, sympatric evolution in Sorghum. Genetics 78:473-474.

Khan JA, Srivastava P, Singh SK (2004). Efficacy of nested-PCR for the detection of phytoplasma causing spike disease of sandal. Curr Sci 86(11):1530-1533.

Mayer CL, Palmer CJ (1996). Evaluation of PCR, nested PCR, and fluorescent antibodies for detection of Giardia and Crytosporidium species in wastewater. App Environ Microbiol 62(6):2081-2085.

Sivaraman L, Gupta VS, Ranjekar PK (1984). Molecular organization of great millet Sorghum vulgare DNA. J Biosci 6:275-281

Snowden JD (1955). The wild fodder sorghums of the section Eu-sorghum. J Linn Soc Bot 55:191-260

Sun Y, Skinner DZ, Liang GH, Hulbert SH (1994). Phylogenetic analysis of Sorghum and related taxa using internal transcribed spacers of nuclear ribosomal DNA. Theor Appl Genet 89:26-32

Tanzer A (2000). Two-dimensional optimization of a seminested PCR for detecting Listeria monocytogenes. Eppendorf Bio News Appl Notes 6:3-4.

Wen WG, Cheng L, Zhang JH, Tan Z (2008). Establishment of semi-nested PCR detection method for trace transgenic rice materials. Food Sci 29(12):622-626 